\title{
Blood Cell Count Ratio Measurement
}

National Cancer Institute

\section{Source}

National Cancer Institute. Blood Cell Count Ratio Measurement. NCI Thesaurus. Code C67208.

The determination of the ratio of one blood cell component lto another in a blood sample. The measurement may be expressed as either a ratio or a percentage. 